\title{
Design of educational and ICT conditions to integrate differences in learning: Contextual learning theory and a first transformation step in early education
}

Citation for published version (APA):

Mooij, T. (2007). Design of educational and ICT conditions to integrate differences in learning: Contextual learning theory and a first transformation step in early education. Computers in Human Behavior, 23(3), 14991530. https://doi.org/10.1016/j.chb.2005.07.004

DOI:

10.1016/j.chb.2005.07.004

Document status and date:

Published: 01/05/2007

Document Version:

Peer reviewed version

Please check the document version of this publication:

- A submitted manuscript is the version of the article upon submission and before peer-review. There can be important differences between the submitted version and the official published version of record. People interested in the research are advised to contact the author for the final version of the publication, or visit the DOI to the publisher's website.

- The final author version and the galley proof are versions of the publication after peer review.

- The final published version features the final layout of the paper including the volume, issue and page numbers.

Link to publication

\section{General rights}

Copyright and moral rights for the publications made accessible in the public portal are retained by the authors and/or other copyright owners and it is a condition of accessing publications that users recognise and abide by the legal requirements associated with these rights.

- Users may download and print one copy of any publication from the public portal for the purpose of private study or research.

- You may not further distribute the material or use it for any profit-making activity or commercial gain

- You may freely distribute the URL identifying the publication in the public portal.

If the publication is distributed under the terms of Article $25 \mathrm{fa}$ of the Dutch Copyright Act, indicated by the "Taverne" license above, please follow below link for the End User Agreement:

https://www.ou.nl/taverne-agreement

Take down policy

If you believe that this document breaches copyright please contact us at:

pure-support@ou.nl

providing details and we will investigate your claim.

Downloaded from https://research.ou.nl/ on date: 26 Apr. 2023 


\title{
Design of educational and ICT conditions to integrate differences in learning: Contextual learning theory and a first transformation step in early education
}

\author{
Ton Mooij * \\ ITS, Radboud University Nijmegen, P.O. Box 9048, 6500 KJ Nijmegen, The Netherlands
}

Available online 12 September 2005

\begin{abstract}
Educational differentiation and ICT can be designed to better recognize and integrate learning differences across students particularly by assisting instructional management and the self-regulation of students. A conceptual framework for such practice is elaborated here. First, learning as an interactional co-constructive process at various levels is considered. The diagnostic, instructional, management, and system aspects of the learning process can be stimulated and maximized. Second, differentiation of learning procedures and materials, design of integrating ICT support, and improvement of development and learning progress are recommended as contextual conditions to optimize the learning process. The combination of the learning aspects with these contextual conditions provides theoretical guidelines for the transition from a nondifferentiating system of education to a differentiating, ICT-based system of instructional management for all students. Information is given about the realization of two of the differentiation guidelines and all ICT design guidelines. The first products were used in kindergarten, to start the improvement of educational practice. This occurred in co-development with kindergarten teachers of three Dutch kindergartens. Information is given about the process and outcomes of this first transformation step in practice. Finally, next co-development steps are discussed.
\end{abstract}

(C) 2005 Elsevier Ltd. All rights reserved.

\footnotetext{
* Tel.: +31 243653558; fax: +31 243653599.

E-mail address: t.mooij@its.ru.nl.
} 
Keywords: Educational differentiation; ICT-designing; Integration of learning differences; Multilevel modeling; Multilevel transformation theory; Software prototype

\section{Introduction}

Designing instruction for students who deviate considerably from their peers with respect to cognitive, social, or learning abilities has been the subject of research for some time already (e.g., Durkin, 1966; Gardner, 1961; Parkhurst, 1922). The questions and problems inherent to the matching of educational and student characteristics have prompted different approaches to the education of students with different learning abilities. For example, a reactive approach to this matching in early education has been developed by Jewett et al. (1998) who introduced various pedagogical, diagnostic, play, and learning materials and procedures for use with kindergarten students experiencing different types of problems. Skinner, Bryant, Coffman, and Campbell (1998) have concentrated on the interactional processes between child and play/learning environment and developed a more preventive approach with a focus on the facilitation of actual developmental levels. According to others, the involvement of parents and professionals from outside the school for extra pedagogical and instructional support starting in kindergarten can be very helpful (Walker et al., 1998). Later curricular, instructional, and social differentiation of the learning process can also promote progress and greater self-regulation of student behavior (Mooij, Terwel, \& Huber, 2000). That is, unsuccessful matching of educational and student characteristics can result in student demotivation, disturbed or withdrawn behavior, aggressive or criminal behavior, and even school dropout (cf. Garnier, Stein, \& Jacobs, 1997; Sherman et al., 1998; U.S. Department of Health, Education \& Welfare, 1973).

Two main categories of student do not fit easily into the regular educational system. The first category consists of children with relatively low learning abilities or innate handicaps (cf. American Psychiatric Association, 1994; Botting, Castilla, Mastroiacovo, \& Siffel, 1998; Hille et al., 1994). To learn more about the educational circumstances for such students, the European Agency for Development in Special Needs Education initiated a comprehensive study of effective classroom practices in 15 European countries (Meijer, 2001, 2003). The methods used were literature review, case studies, expert visits for seven countries, and discussions with experts and Agency Working Partners. The focus of the study was on the revelation, analysis, and description of classroom practices in such a manner that teachers can more easily integrate students with special needs in regular classrooms. The results showed that this 'inclusive' education can be characterized by (a) large differences across countries, (b) behavioral and social-emotional problems of students, and (c) dealing with the diversity within classrooms as one of the biggest problems of teachers (see Meijer, o.c.).

The second category of student not fitting easily into the regular educational system is formed by children scoring above average in one or more domains of 
education, or so-called gifted students. The research devoted to this second category of student is less coordinated than the research concerned with the first category. In general, however, gifted students have been found to also experience various social, emotional, motivational, and achievement problems from a very early age onwards (Davis \& Rimm, 1985; Lloyd, 1999; Mooij, 1999). When Purcell, Burns, Tomlinson, Imbeau, and Martin (2002) considered various curricula, textbooks, international studies, and studies of learning effects in the USA, an immense gap between curricular units and the learning needs of particularly gifted or talented learners was detected, which led the authors to conclude that mediocre educational standards and uninspiring textbooks were largely the case (cf. Lohman, 1990). Massé and Gagné (2002) investigated the social difficulties experienced by talented high school students in Canada with attention to the envy experienced towards other gifted students and the envy experienced by the talented students themselves. The results of the questionnaire research showed greater envy with regard to the social and financial successes of other gifted students than with regard to their academic achievements or intelligence but greater envy of the academic achievements of the talented students themselves.

For both categories of students, timely and adequate knowledge of their learningrelevant characteristics appears to be essential for teachers, parents, and other professionals to provide a stimulating learning environment. Sternberg and Grigorenko (2002) stated that successful intelligence is not completely inborn, which implies that schools can help children maximize their development and expertise. According to Sternberg and Grigorenko, instruction and assessment should help students identify and concentrate on their strengths and compensate for any weaknesses. Instruction and assessment should also help students select and shape the learning environment for maximum adaptation to their learning needs and integrate the different elements of intelligence.

For each child, the relevant diagnostic, instructional, and management features should be available from the first day of education. In addition, these different features must be sufficiently integrated to produce positive learning effects for all children within the group. Relevant innovation or school change processes must also occur at times, which makes for a very complex process (see, e.g., the review of school innovation research by Johnsen, Haensly, Ryser, \& Ford, 2002). Many factors must be considered, designed, coordinated, and checked for their assumed effect on students. However, the information storage and processing capacities of teachers, coaches and the other professionals involved in everyday educational practice are generally limited for groups of 20-30 students (Kounin, 1970; Raver \& Zigler, 1997). Information and Communication Technology (ICT) can help realize desired changes via its ability to log and monitor the different types of play, learning, and teaching characteristics and processes occurring at different times and places (Blumenfeld, Fishman, Krajcik, Marx, \& Soloway, 2000). According to Ayersman and von Minden (1995), computers can help differentiate learning in terms of such categories as cognitive control, cognitive style, learning style, and personality type. Similarly, ICT has the potential to integrate and optimize information regarding instruction, learning, and the characteristics of the educational system at a variety 
of levels (cf. Ely, 1999; Watkins, 2001). Therefore, the question for research is whether it is possible to design and integrate various educational and ICT factors in such a manner that the learning differences between students can be better recognized and integrated.

A first activity in answering the aforementioned question with regard to instructional design is to elaborate a theoretical framework that is also relevant for actual practice (Earle, 2000). For this purpose, learning as a co-constructive process that occurs at different levels will be considered. In order to facilitate the recognition and integration of differences in learning, a number of the educational conditions needed to individualize the curriculum and optimize student development will also be specified (cf. Gustafson, 2002; Kemp, 2000; Mooij, 2002). Theoretically, the combination of these contextual conditions with the different learning process aspects is expected to build a flexible and transparent multilevel system of education and thereby facilitate the recognition and integration of learning differences.

A second activity to answer the research question concerns the realization of these contextual learning conditions in educational practice. Some general guidelines based on these conditions are made concrete, including a general software prototype. Then the focus is on theoretically guided changes of educational practice in three Dutch kindergartens, to start the improvement of development and learning progress. The concrete experiences with this first educational transformation step also suggest next steps to transform nondifferentiated education into an integrated, ICT-based system to promote instructional self-regulation on the parts of all students.

\section{Contextual learning theory}

\subsection{Development domain, interactional learning, level of competence}

Children differ with respect to an innate "internal structure of potential skills" or more or less general domains of development (Gallagher, 1975; Magnusson \& Allen, 1983). Examples are the social-communicative domain of development (Goleman, 1995), the general intellectual domain of development (Collier, 1994), specific intellectual domains of development such as language (Byrne, 1998) or mathematics (Borko, Davinroy, Bliem, \& Cumbo, 2000), the motor domain (van den Einden \& Pecht, 1995), the creative domain (Jellen \& Urban, 1986), and the emotional domain (Frijda, 1994). The characteristics of the innate internal structure and characteristics of the immediate environment constantly affect a child's actual behavior and behavioral potential (cf. Leseman, 2002; Mönks \& Lehwald, 1991). Learning can thus be defined as an interactional process via which the individual develops his or her potential skills within various developmental domains into actual competencies or levels of achievement (Heckhausen, 1980; Khatena, 1982; Mehlhorn, 1988). The level of competence with respect to a particular domain of development can be defined as the degree to which a child's behavior matches specific criteria, standards, or norms. 
Both the home situation and pedagogical or educational institutions can then produce differences in children's competencies, skills, cognitions, beliefs, and attitudes (Jones, Gullo, Burton-Maxwell, \& Stoiber, 1998; Marjoribanks, 1994).

\subsection{Individual learning characteristics and learning progress}

Children develop different competencies by actively seeking specific information, constructing knowledge, and displaying different types of behavior. Children may differ with regard to the extent to which they favor a specific learning strategy; their development may be largely self-regulated, for example, or they may look for detailed pedagogical, didactic, or coaching support. Sternberg and Grigorenko (2002) have defined successful intelligence as "the ability to succeed in life according to one's own definition of success, within one's sociocultural context, by capitalizing on one's strengths and correcting or compensating for one's weaknesses; in order to adapt to, shape, and select environments; through a combination of analytical, creative, and practical abilities" (p. 265). People can vary with regard to their ability to analyze, judge, critique, compare and contrast, evaluate, and explain. Successfully intelligent persons do well in school and on standardized tests. And people can vary with regard to their ability to create, invent, discover, explore, imagine, and suppose. According to Sternberg and Grigorenko, creativity is the ability to generate ideas that are novel, high in quality, and task appropriate. People can vary also with regard to their ability to use, utilize, apply, implement, and put things into actual practice. A practical person "shows intelligence in highly contextualized situations" (p. 266). The authors hypothesized that a set of universal processes underlies all aspects of intelligence. More specifically, there are metacomponents or executive processes, performance components that execute the instructions provided by the metacomponents, and knowledge-acquisition components that are used to learn how to solve problems and acquire declarative knowledge.

In order to optimize the learning of each student, curricular and instructional characteristics should be based on the learning characteristics and strategies of the individual student within the small group or class. In addition, the student should be stimulated at a level somewhat above his or her actual level of competence (Cronbach, 1970). When such matching does not occur across a longer period of time, negative motivational, emotional, behavioral, cognitive, or social effects may be the result. Relatively low-ability learners may thus benefit from specific and carefully ordered steps of competency, as in programmed instruction or mastery learning (Bloom, 1968). Conversely, Purcell et al. (2002) have argued that the instruction of gifted students "should include open-ended questions and activities, as well as choices related to learning activities and topics" (p. 309).

\subsection{Group characteristics, evaluations of learning, and individual/group effects}

Most students learn within a group situation, which may be the small group or class. Curricular and instructional prescriptions determine the extent to which 
student learning occurs individually or involves some type of group work. That is, group instructional characteristics can promote or block various individual and group learning processes (Dillenbourg, 2002; Jochems, 2002). Interactions between various individual and group characteristics may also occur and relate to the content of the task or lesson, the degree of pedagogical-didactic differentiation, and means of evaluation (cf. Ames, 1984; Kirschner, 2002). Individual evaluation based on a learner's progress with respect to a specific set of learning activities is criterion-referenced and will usually be positive, which can then - in turn - motivate the learner (Heckhausen, 1980). Given the same individual progress, evaluation based on the group or normed mean can indicate insufficient achievement progress or school marks and therefore be negative, which can demotivate the learner in the long run. On the other hand, the students who achieve relatively best compared to the group mean are motivated and will do better. These contrasting motivational and achievement effects are known as frog pond effects (Davis, 1966) or Matthew effects (cf. Aarnoutse \& Verhoeven, 2003).

Assessment procedures that are not criterion-referenced and only mean-based can be particularly handicapping for learners who - for whatever reason - initially score significantly above or below their peers (Collier, 1994). This is revealed by student monitoring systems that are based on normed means (see, for example, Evers et al., 2002; Kemp, 2000; Kuhlemeier, Kleintjes, \& van den Bergh, 2001). Peetsma, van der Veen, Koopman, and van Schooten (2003) conducted a longitudinal multilevel study of the class effects on the progress of about 6000 Dutch students between the ages of 10 and 12 in four areas of competence for about 460 elementary classes. Of particular interest were the influence of ethnic minority composition and the degree of heterogeneity along these lines on student growth within the domain of math, Dutch language, cognitive selfimage, and feelings of well-being. These issues were analyzed while controlling for pretest scores, IQ, sex, age, level of parental education, and ethnic background. For math in general, the higher the percentage ethnic minority students in the class, the lower the math progress; for two of the ethnic minority groups, however, classes with more than $30 \%$ ethnic minority students were found to produce relatively greater math progress for the ethnic minority students when compared to the other students. For language in general, the higher the percentage students with low-educated parents in the class, the lower the progress for Dutch language; for the classes with lower educated parents, however, relatively greater language progress was shown by particularly the students of the lowereducated parents. Comparable results were nevertheless not found for self-image or feelings of well-being.

The aforementioned multilevel results confirm the assumption that the interactional effects of various kinds of group and individual characteristics can differ according to school subject. Knowledge of these complex interactions can be used to improve the design of education for students at all levels (cf. Lajoie, 2003; Mooij, 2005). 


\subsection{Multilevel diagnostic, instructional, management, and system aspects}

The preceding information suggests that learning must start with some type of diagnostics with respect to the level of competence of the individual student within a specific domain and the context of peers. Specific instructional guidelines or prescriptions can then be developed on the basis of such diagnostics to assist each learner, small group, or class. The related learning processes and effects can be evaluated and managed in order to provide for further positive learning steps. And finally, diagnostics, instruction, and management have to be integrated within a sufficiently flexible multilevel system to provide adequate support for the differences in learning and development across students. A model to illustrate this cyclic process of diagnostics, instruction, and management within a multilevel system (DIMS) is presented in Fig. 1.

The lowest level in Fig. 1 involves the individual learner. In a differentiating educational system, teachers, parents, and other pedagogical and health care professionals can concentrate diagnostic, instructional, and management characteristics on the provision of preventive support for slower or 'non-regular' learners and the adequate stimulation of highly able or gifted learners with completely different instructional content and procedures much more easily than in a nondifferentiating

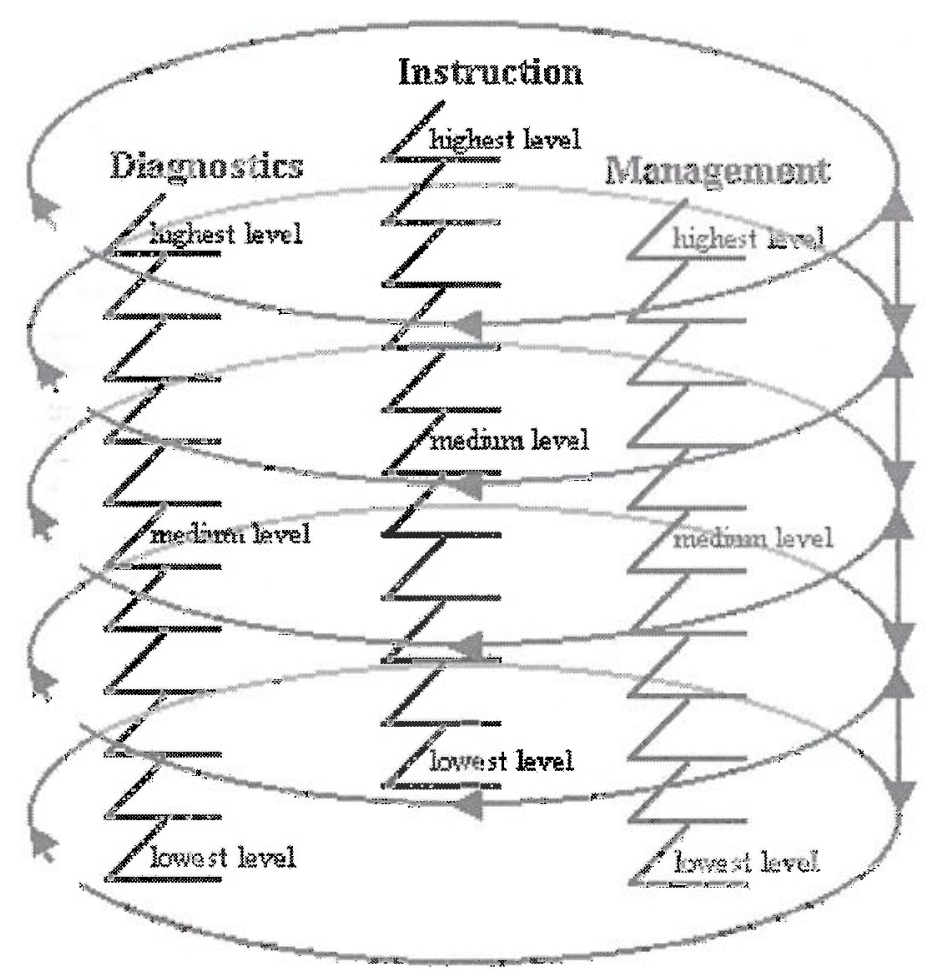

Fig. 1. Modeling of multilevel diagnostic, instructional, and management systems (DIMS). 
system. In a differentiating system, initially low achievers can do something better and initially high achievers can do something much better. At the higher level of the small group or class, the degree of instructional differentiation will then correlate with mean achievement and heterogeneity of achievement.

At the level of the school, diagnostic, instructional, and management characteristics can reflect school policy or ethos, priorities set by school leaders, and the regional interrelations related to socio-economic neighborhood. At this level, student means and heterogeneities reflect primary, secondary, and tertiary educational and organizational processes. And ICT-based monitoring can provide the school team and management with integrated longitudinal data on the achievement of the individual, small group, class, and school. At the municipal or regional levels, moreover, specification of curricular content can promote ICT-supported collaboration or differentiation between schools and other institutions with respect to the needs of specific learners. Such collaboration or differentiation can then lead to - for example-more preventive integrated coaching by teachers, parents, and external professionals (cf. Gilsing, Roes, Veldheer, \& Vorthoren, 2000).

At the national and international levels, normed psychometric indicators can be used as benchmarks for the assessment and comparison of learning and competency within and across schools. National educational policies and national educational support agencies can be coordinated with the aid of ICT-based bottom-up data. Compared to a nondifferentiating system with little or no ICT-based education, differentiated ICT-based education can be expected to provide greater reliability, validity, and efficiency of data collection and greater ease of analysis, evaluation, and interpretation at any educational level (cf. Fig. 1).

\subsection{Designing integration of learning differences by three types of conditions}

The European Agency for Development in Special Needs Education has recommended the following practices as most effective for the establishment of inclusive classrooms: (a) cooperative or team teaching, (b) cooperative learning or peer tutoring, (c) individual planning, (d) collaborative problem solving, and (e) heterogeneous grouping with flexible instruction and differentiation (Meijer, 2001, 2003). Johnsen et al. (2002) mentioned the following as particularly effective for the adaptation of general classroom practices to the needs of gifted students: (a) acceleration, (b) curriculum compacting, (c) enrichment, (d) use of learning centers, (e) creative problem solving, (f) independent study, (g) interdisciplinary curricula, (h) problem-based curricula, and (i) recognition of instructional style preferences.

Integration of these two research outcomes into the DIMS aspects of the learning model in Fig. 1 results in three contextual conditions that seem essential for the educational recognition and integration of differences in learning (cf. also Mooij, in press). The first condition pertains to differentiation of learning procedures and materials to facilitate not only diagnostics but also adequate individualization of the instructional process. In other words, this condition concerns the relations between the various diagnostic and instructional aspects of learning. The second 
condition is the design and use of integrating ICT to enable information connections between the various diagnostic, instructional, and management features and the system transformation needed to recognize and integrate differences in learning across students. The third condition involves the improvement of development and learning progress, or the facilitation and optimization of selected level-specific and between-level interactions which can help link the instructional and management aspects of learning processes and outcomes.

In the following, the diagnostic, instructional, management, and system aspects of the multilevel model of student learning will be considered for each of the three contextual conditions seen as essential for the educational recognition and integration of differences in student learning.

\subsection{Differentiation of learning procedures and materials}

Differentiation of learning procedures and materials is defined as the structured adaptation or individualization of the curriculum to the learning characteristics and potentials of individual students and small groups of students. A curriculum refers to specific content-based concepts, subconcepts, and themes with different learning activities representing specific types of knowledge, skills, and competencies or aptitudes and attitudes. A curriculum is designed to inspire, motivate, support, and challenge learners with the corresponding learning activities. An overview of curricular differentiation aspects relevant to learning can be found in the second column of Table 1 .

\subsubsection{Identify a pedagogical didactic kernel structure with competence (sub)domains}

Curricular differentiation has to reflect the order, evaluation or measurement of the development and learning processes associated with the relevant learning procedures and materials. From a diagnostic point of view, learning procedures and materials can be organized in more or less hierarchically structured competence domains and sub-domains like language, general cognition, social-emotional performances, and mathematics. Competence domains and sub-domains reflect structured sets of learning procedures and materials which order, evaluate or measure the relevant development and learning processes. The term pedagogical-didactic kernel structure (PDKS) can be used to indicate the corresponding structure based on normed instruments to assess related levels of competency, or skills (cf. Mooij, 2004).

\subsubsection{Structure competence (sub) domains into (sub) skills and instructional lines}

Curricular learning activities and materials, including intermediate and final performance or achievement tests, constitute competence (sub)domains and (sub)skills of the official curriculum and characterize the particular type of education. While school curricula reflect the educational identity of a school, the national curriculum sets learning standards and examination norms for specific learning processes. Curricular units and subunits can be seen as content-based streams of learning activities and can be used to structure students into flexible groups. Learning activities and 
Table 1

Theoretical guidelines to improve instruction and learning by types of contextual conditions and DIMS aspects

\begin{tabular}{|c|c|c|c|}
\hline \multirow[t]{2}{*}{ Learning aspect (DIMS) } & \multicolumn{3}{|l|}{ Type of contextual condition } \\
\hline & $\begin{array}{l}\text { Differentiation of learning procedures } \\
\text { and materials }\end{array}$ & $\begin{array}{l}\text { Design and use of integrating ICT } \\
\text { support }\end{array}$ & $\begin{array}{l}\text { Improvement of development and } \\
\text { learning progress }\end{array}$ \\
\hline Diagnostic & $\begin{array}{l}\text { 1. Identify a pedagogical-didactic kernel } \\
\text { structure with competence (sub)domains }\end{array}$ & $\begin{array}{l}\text { 1. Facilitate construction and use of a } \\
\text { pedagogical-didactic kernel structure }\end{array}$ & $\begin{array}{l}\text { 1. Use a learner's entry characteristics } \\
\text { to assign instructional (sub)lines }\end{array}$ \\
\hline Instruction & $\begin{array}{l}\text { 2. Structure competence (sub)domains } \\
\text { into (sub)skills and instructional lines } \\
\text { 3. Include psychometrically valid } \\
\text { indicators to evaluate learning progress }\end{array}$ & $\begin{array}{l}\text { 2. Facilitate structuring, transparency, } \\
\text { and flexible use of instructional lines } \\
\text { 3. Facilitate individualized instruction, } \\
\text { collaborative learning, and self-regulation }\end{array}$ & $\begin{array}{l}\text { 2. Create and control prosocial } \\
\text { relationships in and around school } \\
\text { 3. Use collaborative didactic procedures } \\
\text { to support learners' self-regulation }\end{array}$ \\
\hline Management & $\begin{array}{l}\text { 4. Organize and match flexible groups of } \\
\text { learners and teachers/coaches }\end{array}$ & $\begin{array}{l}\text { 4. Facilitate multilevel organization and } \\
\text { differentiated evaluation of learning }\end{array}$ & $\begin{array}{l}\text { 4. Concentrate teacher coaching on } \\
\text { those learners who most need this }\end{array}$ \\
\hline System & $\begin{array}{l}\text { 5. Use integrated systems for monitoring, } \\
\text { evaluation, and administration }\end{array}$ & $\begin{array}{l}\text { 5. Integrate instruction and learning in } \\
\text { different contexts, in longitudinal designs }\end{array}$ & $\begin{array}{l}\text { 5. Use multilevel indicators to improve } \\
\text { instruction and learning progress }\end{array}$ \\
\hline
\end{tabular}


Table 2

Multilevel curricular structure and differentiation of instruction and learning

\begin{tabular}{ll}
\hline Curricular level & Instruction/learning \\
\hline $\begin{array}{l}\text { 10. International curriculum } \\
\text { 9. National curriculum }\end{array}$ & $\begin{array}{l}\text { Similarities and differences in educational systems across countries } \\
\text { National educational system, examination requirements, educational } \\
\text { policy } \\
\text { Instructional lines characterizing schools and institutes within a } \\
\text { particular region, district, or community }\end{array}$ \\
8. Regional curriculum & $\begin{array}{l}\text { Instructional lines characterizing the type(s) of education for one school } \\
\text { Instructional lines characterizing the type(s) of education for one school } \\
\text { location }\end{array}$ \\
7. School curriculum & $\begin{array}{l}\text { A set of instructional lines characterizing a specific type of education; can } \\
\text { also be used to structure students into groups (e.g., into the lowest, } \\
\text { middle, or highest curricular levels for a location or school) } \\
\text { A subset of instructional lines characterizing a specific type of education; } \\
\text { can also be used to structure students into groups }\end{array}$ \\
5. Curricular unit & $\begin{array}{l}\text { Ordered arrangement of learning activities; may include evaluative or } \\
\text { normed learning activities as indicators of a specific level of difficulty }\end{array}$ \\
3. Instructional line & $\begin{array}{l}\text { Specific knowledge, skills, competencies, aptitudes, or attitudes to be } \\
\text { mastered or learned } \\
\text { Element of a learning activity }\end{array}$ \\
2. Learning activity & 1. Task
\end{tabular}

tasks - defined as the elements of learning activities - can be ordered along instructional lines, which may include evaluative or normed indicators for a specific level of difficulty (cf. Brush \& Saye, 2001). An overview of the multilevel structure of curricular concepts and their instructional and learning relevance is given in Table 2.

Evaluation or test procedures and the corresponding learner selection processes are intended to see that each learner develops and learns according to the curriculum (cf. also Nadolski, Kirschner, van Merriënboer, \& Hummel, 2001; van den Akker, 1999). In addition to the official curriculum, many free activities can be chosen or developed by the learners themselves (cf. Pellegrini \& Boyd, 1993) and later evaluated by the learners themselves or in cooperation with the teacher.

\subsubsection{Include psychometrically valid indicators to evaluate learning progress}

Different indicators can be integrated into the instructional lines of the curriculum in order to evaluate the specific development and learning of each learner (cf. Meisels, DiPrima Bickel, Nicholson, Xue, \& Atkins-Burnett, 2001). A first evaluation variant is the use of psychometrically normed indicators for the various domains, sub-domains, skills or sub-skills of the learning processes. At the national level, different types of norms for all educational types can be established (e.g., an architecture of age-normed means for concepts measured by various screening instruments or tests). A PDKS would enable coherent evaluation of learning competency or progress at the levels of, for example, the individual, small group, class, school, or nation. A learner's school path can then be determined on the basis of individual progress against a background of different types of means and norms. In other words, evaluation can occur independent of comparison to only school 
Table 3

Pedagogical-didactic kernel structure (PDKS) and normative concepts

\begin{tabular}{|c|c|c|}
\hline Curricular level $^{\mathrm{a}}$ & Normative concepts & Definition of concepts \\
\hline 9. National curriculum & $\begin{array}{l}\text { Pedagogical-didactic kernel } \\
\text { structure (PDKS) }\end{array}$ & $\begin{array}{l}\text { Set of ordered concepts used to reliably } \\
\text { and validly assess learning progress } \\
\text { within specific (sub)domains or (sub)skills } \\
\text { for one or more learners in a standardized } \\
\text { manner }\end{array}$ \\
\hline 7. School curriculum & PDKS at the level of the school & $\begin{array}{l}\text { Subset of PDKS selected by a school to } \\
\text { assess progress of students }\end{array}$ \\
\hline 6. Location curriculum & PDKS at the level of the location & $\begin{array}{l}\text { Subset of PDKS selected by a school } \\
\text { location to assess progress of students }\end{array}$ \\
\hline 3. Instructional line & Normed instructional line & $\begin{array}{l}\text { Set of related learning activities with at } \\
\text { least one learning activity or task serving } \\
\text { as a progress indicator for the PDKS }\end{array}$ \\
\hline 2. Learning activity & Normed learning activity & $\begin{array}{l}\text { Learning activity serving as a progress } \\
\text { indicator for the PDKS }\end{array}$ \\
\hline 1. Task & Normed task & $\begin{array}{l}\text { Task serving as a progress indicator for } \\
\text { the PDKS }\end{array}$ \\
\hline
\end{tabular}

${ }^{\text {a }}$ Cf. Table 2.

and peer means or the traditional grading system. An overview of some relevant progress indicators is provided in Table 3.

A second evaluation variant is more content-based with respect to the concepts, sub-concepts, themes, and learning activities related to the PDKS. This variant concerns the degree of mastery for specific information, competencies, or behavior. Evaluation is now based on the individual, subjective judgments of the teachers and other individuals involved in the education of students. The evaluation process thus relates to the group of learners within a class or school and enables more learner- or situation-specific evaluation.

A third evaluation variant involves an integrated combination of the first and second variants. Both the PDKS and relevant evaluation methods are considered, on the one hand, and content-based individual or group variations, on the other hand. Different evaluation possibilities, which can often be made more user-friendly when ICT-based, are thus available. One example of such a combined approach to evaluation is the human benchmarking of O'Neil, Ni, Baker, and Wittrock (2002) who assessed the quality of individual problem solving against a range of expert problem-solving achievements.

\subsubsection{Organize and match flexible groups of learners and teachers/coaches}

Making the organization of learners more flexible by matching their entry characteristics or instructional needs is another conditional guideline that may clearly promote the recognition and integration of learning differences (Bennathan \& Boxall, 1996; Cooper \& Ideus, 1998; Kanselaar, 2002; Underwood, 2003). Flexible small learner groups can be formed, for example, on the basis of initial competency levels, learning style, specific instructional requirements in the case of particular 
handicaps, or giftedness (Gross, 1996, 2001). Such matching is in line with an Aptitude-Treatment-Interaction design (ATI design; Cronbach \& Snow, 1977) and can greatly facilitate multilevel effects on learner progress. Along these lines, Tennyson and Breuer (2002) have adopted an interactional cognitive learning and thinking model. Of particular interest are the interactions of content knowledge and cognitive learning strategies with such higher order cognitive processes as problem solving and creativity. The authors developed the Minnesota Adaptive Instructional System (MAIS) to improve learning using complex and dynamic computer simulation techniques. One of the main research outcomes was that group membership based on similar cognitive ability best promoted the development of thinking strategies.

\subsubsection{Use integrated systems for monitoring, evaluation, and administration}

The systematic and integrated registration, evaluation, and administration of results is yet another condition that can help recognition and integration of differences in learning. The registration of results with respect to instructional lines, for example, can produce transparency and thereby insight into learner progress and any potential learning problems. ICT-based registration, evaluation, and administration can also link different levels of information and thereby provide insight into the progress of various individuals, groups, schools, and institutions. Moreover, ICT-based indicators can provide a common pedagogical-didactic language for instructional clarity, the flexible design of learning arrangements for individual learners or groups of learners, and evaluation by teachers, parents, and other professionals either inside or outside the school.

\subsection{Design and use of integrating ICT support}

One of the main functions of ICT support involves the linking of different types of information for various learners or groups of learners across time, place, and media (Sinko \& Lehtinen, 1999). In doing this, ICT has an obvious and major role to play in the various diagnostic, instructional, management, and system aspects of student learning - as can be seen in Table 1 .

\subsubsection{Facilitate construction and use of a pedagogical didactic kernel structure}

In a differentiating ICT-based educational system, a PDKS can provide a psychologically valid and normed basis for the assessment of learning progress and flexible integration of differences in learning. For example, ICT can help build a normed reference system of competencies measured in a psychometrically reliable and valid manner and then provide immediate feedback to local users with regard to specific characteristics of the curriculum and relevant learning processes and effects.

\subsubsection{Facilitate structuring, transparency, and flexible use of instructional lines}

ICT can help further structure, enhance the transparency of, and promote the use of the curriculum across the different educational levels (see Fig. 1 and Table 2). For 
example, the establishment of instructional lines with respect to specific groups of learners and for the qualitative or quantitative analysis of multilevel data for research and development purposes can be undertaken (Cronbach, 1983). For national and international management and policy purposes, ICT can provide data and feedback with respect to many different psychological, learning, and instructional factors. Furthermore, the nationally normed benchmarks related to the PDKS can be used to locally construct or complete instructional lines and evaluate student learning from a multilevel perspective. The relations between national and local benchmarks or evaluation outcomes can also be used to qualify local features and identify possible areas for improvement.

\subsubsection{Facilitate individualized instruction, collaborative learning, and self-regulation}

ICT can help individualize instruction and transform learning into pedagogically responsible self-management. Hooper (2003) compared groups of students with different levels of persistence for their ability to learn from computer-based instruction within cooperative groups and found average persisters to interact more than high or low persisters. ICT can thus play a role in the creation of support for learners with different abilities and levels of persistence by preselecting particular content or procedures and thereby helping users to regulate their own learning. In other research, van Merriënboer (1997) and van Merriënboer, Kirschner, and Kester (2003) have concentrated on the development of a theoretical framework and instructional software for complex learning. These authors presented information on a four-components instructional design model (4C ID model) and emphasized the use of authentic and complex learning tasks. Instructional design should focus a combination of performance support and fading, by scaffolding whole-task practice. This can be realized by simple-to-complex sequencing of whole tasks into task classes, and by differentiation between types of learning tasks, e.g., from worked-out examples or completion assignments to conventional tasks. Instructional design can also promote learning by just-in-time presentation of information about the nature of the learning tasks. Supportive information is presented before equivalent learning tasks; procedural information is supplied during specific task performance.

Kuo et al. (2002) have similarly designed an intelligent web-based interactive language-learning system to support English learning via the internet. And when Calisir and Gurel (2003) investigated the influence of text structure and prior knowledge on reading comprehension, browsing, and perceived control, the use of hierarchical hypertext was found to be most appropriate for nonknowledgeable learners. The use of the computer to support instructional management is - in and of itself - also an issue for further research. Chalmers (2003) has examined the interactions between people and the computer and suggested that the human-computer interface requires very different characteristics or forms of interaction due to differences in the cognitive functioning and representations of the users. In other words, research on the human computer interface should be undertaken in addition to research on learning, the retention of information, the organization of information, and individual differences. 


\subsubsection{Facilitate multilevel organization and differentiated evaluation of learning}

The multilevel organization and evaluation of learning can be clearly facilitated by ICT. For example, individual students or groups of students can work along instructional lines while being coached by teachers, parents, or external professionals located in other places and working at different times. Within an instructional line, specific characteristics or items on a questionnaire, observation list, test, or topic can be referred to in a specific order and the degree of progress then specified with respect to various types of users, various types of institutions, or various levels of functioning. An example of the multilevel organization and interactional sharing of information is provided by Bennett, Schreiber, and Andrews (2002) who developed a competency-based method to train aircrew members both individually and collectively using real, virtual, and computer-generated systems. Their Distributed Mission Training (DMT) involves a network of individual cockpits and visual systems that thus allow interactive training using both single and multiple aircraft. In other words, DMT involves the dynamic sharing and use of simulated information among a group of individuals engaged in real-time training scenarios.

\subsubsection{Integrate instruction and learning in different contexts, in longitudinal designs}

ICT can integrate multilevel diagnostic, instructional, and management aspects of learning and different categories of users across time, place, and media. ICT can do this in a systematic way, for different fields or structures.

\subsection{Improvement of development and learning progress}

The improvement of development and learning progress is defined as the matching of specific instructional lines with specific learners or groups of learners in such a manner that maximum learning progress is realized for each individual learner. Five conditional guidelines can be distinguished with respect to this improvement: see the fourth column of Table 1 .

\subsubsection{Use a learner's entry characteristics to assign instructional (sub) lines}

Entry characteristics function as first pedagogical, didactic, or instructional diagnostics to support and guide a learner's ways through a structured set of instructional (sub)lines, in multiple learning settings. Differences in the initial characteristics of learners and their levels of initial competence can be expressed as differences in entry characteristics. Along these lines, Jewett et al. (1998) and Walker et al. (1998) have considered early identification and compensating measures for kindergarten students achieving very low within the social and cognitive domains. Early information from parents and teachers was combined to adapt the pedagogicaldidactic characteristics of the curriculum to the characteristics of the students actually present in the class which had positive effects on the functioning of the students. On a different note, Caplan, Henderson, Henderson, and Fleming (2002) investigated which socio-emotional variables were relevant for the adjustment of early-entrance college students - defined as gifted students entering college early 
because of acceleration during elementary or high school - and found no detrimental effects for accelerated students when compared to nonaccelerated students (see also Gross, 1992). Caplan et al. also investigated the role of self-concept and perceptions of family environment in the psychosocial adjustment and achievement of accelerated college students within a residential early-entrance-to-college program and found family cohesion, conflict, expressiveness, and overall self-concept to be predictive of adjustment to college. Furthermore, family cohesion, organization, control, conflict, and overall self-concept predicted academic achievement as measured by first-semester grade-point average.

When Veenman, Prins, and Elshout (2002) examined the role of metacognitive skills and intellectual ability among university students during an initial inductive learning task involving a complex computer simulation, they found the learners to initially manipulate the input variables in a qualitative manner and thereby create examples of situations for the induction of qualitative rules. Once some of the relevant variables were identified, the learners then developed hypotheses and theories about the relations between the variables. When the learners confronted a task that was far below or far above their capacities, the role of intellectual ability was found to be relatively small. This finding led the researchers to conclude that metacognitive awareness and skill play a critical role in learning. That is, learners with a high level of metacognitive skill performed more actions in the laboratory, which then led to greater qualitative knowledge while greater quantitative knowledge was acquired by learners with high intellectual abilities.

Cognitive load theory has examined cognitive processing and the structuring of information into appropriate instructional designs (Paas, Renkl, \& Sweller, 2003). In general, instructional designs are used to specify how a person is expected to learn and how the person can learn most efficiently when it comes to complex learning tasks (van Merriënboer et al., 2003). According to cognitive load theory, instruction should be based on each learner's initial level of competence. Kalyuga, Ayres, Chandler, and Sweller (2003) have shown those instructional designs that are effective with inexperienced learners to lose their effectiveness and even have negative effects when used with more experienced learners - which the authors have called "the expertise reversal shift".

\subsubsection{Create and control prosocial relationships in and around school}

In general, the creation and stimulation of a prosocial pedagogical climate is an important instructional condition (Alschuler, 1980). Teachers may realize this by making students responsible for the formulation and enforcement of positive rules of conduct. The involvement of learners in the definition of prosocial behavior and behavioral rules should then occur from the first day of school (Mooij et al., 2000). Collaborative didactic procedures can also be integrated into different instructional lines (cf. Kaplan, Gheen, \& Midgley, 2002). According to Kreijns, Kirschner, and Jochems (2003), the social collaboration in small groups requires specific didactic support to result in positive group processes and outcomes (also see Crook, 1998). Gentry, Rizza, and Owen (2002) investigated the perceptions of challenge 
and choice for teachers versus students, on the one hand, and ordinary versus gifted students, on the other hand. With respect to their perceptions of challenge, no relations were detected between what teachers report and students report during elementary or high school. With respect to perceptions of choice, only a small positive correlation was found for the reports of teachers and students during elementary school, which suggests that the reports of teachers may not always reflect the actual experiences of their students. Regarding the perceptions of challenge on the parts of ordinary versus gifted students, gifted students attending magnet schools reported significantly greater challenge in their school activities than gifted and other students attending a regular middle school. No differences were found at the elementary school level.

\subsubsection{Use collaborative didactic procedures to support learners' self-regulation}

The use of collaborative instructional procedures to support self-regulation can motivate learners and thereby promote both individual and group learning outcomes. Bergqvist and Säljö (1998) found collaboration among seven- to nineyear-old elementary students in Sweden to greatly facilitate the transfer of many responsibilities from the teacher to learners. According to the authors, this was made possible by the social, pedagogical, and learning roles being closely related to the organization of the teaching and learning within the age-integrated classes using an individualized curriculum (cf. Jones, Rasmussen, \& Moffitt, 1997).

In research by Neber and Schommer-Aikins (2002) on self-regulated learning among highly gifted elementary and high-school students, self-regulated learning was defined as the ability to direct one's own learning with respect to both content and process. The gifted elementary students showed a higher level of investigation in the science environment and less test anxiety and work avoidance than the gifted high-school students. The science-related motivational beliefs of the highly gifted boys proved more positive than the science-related motivational beliefs of the highly gifted girls. The level of investigation in the science learning environment was found to provide the motivational and epistemological prerequisites for self-regulation on the part of all the gifted students, which led the researchers to conclude that exploration and discovery should be clearly promoted in the science curricula for highly gifted students (cf. also Freeman \& Josepsson, 2002).

\subsubsection{Concentrate teacher coaching on those learners who most need this}

With the encouragement of self-regulation on the part of learners, teachers can devote greater attention to those learners who need extra guidance or coaching without the progress of the other children in the class suffering. On the one hand, it is usually the teacher who must specify how learning activities should proceed when a learner encounters problems, which means that time must be made available for this. On the other hand, learners can learn from helping each other and explaining things to each other, which means that they need not necessarily suffer from less teacher attention. When Jewett et al. (1998) examined the pedagogical and curricular factors that enabled kindergarten teachers to help children with special needs, they 
found curricular adaptations and teacher assistance for learners at risk to clearly reduce the motivational and achievement problems of such children.

\subsubsection{Use multilevel indicators to improve instruction and learning progress}

With the use of integrated systems for the registration, evaluation, and administration of learner progress, it is possible to measure and check the progress of students on a number of different levels. The teacher can involve other learners, other teachers, parents, or professionals from outside the school in the initial diagnostic process, the learning process, the design of interventions, and the evaluation of outcomes. In a longitudinal intervention study of eight elementary schools with about $50 \%$ disadvantaged students by Johnsen et al. (2002), the principals were informed about the intervention and mentor teachers were then selected and trained to collaborate with 71 cohort teachers. Systematic classroom observations aimed at the assessment of instructional variation in lesson content, timing of instruction, rate of assessment, environmental involvement, and student choice of lessons or lesson materials showed greater adaptation of teachers to the individual differences among students following training. The researchers concluded that "transformational changes in environment and preference occurred first for the majority of teachers, perhaps because they were more visible or easier to accomplish. It did appear that changes in environment or preference were precursors to more substantial changes in rate and content (...)" (p. 61).

\subsection{Multilevel hypothesis}

A general multilevel hypothesis formulated on the basis of the aforementioned modeling can be formulated as follows: The higher the degree of realization for the three conditions known to facilitate the recognition and integration of learning differences, the higher the multilevel differentiation of the learning process, differentiated evaluation of the learning process, and learning outcomes for particularly those students who initially deviate the most from the mean for their peer group or class.

Two main arguments underlie this general hypothesis. First, use of a PDKS realizes the adequate design and differentiation of learning arrangements. This will produce a more supportive, more motivating, and more productive learning environment and thus more positive learning effects (cf. Schnotz \& Lowe, 2003). Second, the provision of integrating ICT will create greater opportunities for self-regulation of the learning process. With a shift from a nondifferentiating to a differentiating ICT-based educational system, thus, teachers and other professionals can provide greater support for slower or less capable learners while gifted learners are encouraged to regulate their own learning in a most stimulating manner (cf. King et al., 1985).

The general hypothesis outlined above can be checked empirically when the three types of contextual conditions have been realized at least in part. A first priority along these lines, then, is the development of a concept PDKS and a corresponding 
software prototype (see columns 2 and 3 of Table 1 ). Both are necessary to start the adequate recognition and integration of learning differences in educational practice or, in other terms, to transform the educational system. A second priority is the corresponding user-based change of educational practice, to realize and check the contextual improvement guidelines of column 4 in Table 1.

\section{Method}

\subsection{Constructing a concept PKDS and a general software prototype}

An inventory was made of Dutch diagnostic and achievement tests for youth aged 0-20 across various fields including psychology, youth health, and education. Relevant handbooks (Evers, van Vliet-Mulder, \& Groot, 2000; Evers et al., 2002; Resing et al., 2002) and internet information of Dutch institutes for educational policy, assessment, and development were the main sources of information. Instruments or tests selected were checked for reliability, concept validity, or criterion validity. Normed concepts and sub-concepts measuring comparable behavior or performances were tentatively organized into provisional 'tree-structures' concerning competence domains, sub-domains, skills, and sub-skills.

The features of this concept PDKS were used in the design process of integrating ICT. Relevant design characteristics were discussed and evaluated mainly by the researcher team and the software developers involved. The potential use of the tree-structures in educational practice raised issues concerning different types of activities according to the four learning aspects (diagnostic, instructional, managerial, and systemic: see Table 1). Following this, the characteristics and functioning of a general software prototype were designed and created in the form of an internet-based computer program. The program design concentrated on the support of each of the contextual guidelines of the differentiation of learning procedures and materials, hence the acronym 'DIMS' (diagnostic, instructional, and management systems). The combination of the concept PDKS and the general software prototype DIMS generated issues about concrete forms and interfaces in practice. This required the specification and use of both PDKS and DIMS in educational practice, to try to improve practice according to the improvement guidelines of Table 1.

\subsection{Co-development in kindergarten practice}

Clark and Estes (1999) illustrated the relevance of co-development between practice and research. These authors used a cycle of development beginning with descriptive and empirical research; construction of generic technology; contextualization of the technology to generate new issues for further research; continuation with the next cycle of development; and so on. In the present situation, teachers and school staff can collaborate with research and other development specialists to specify software features and to insure the validity of the innovation and transformation processes 
(cf. Crosier, Cobb, \& Wilson, 2002; Kensing, Simonsen, \& Bødker, 1998; Proudfoot et al., 2003). Wilson (1999) stated that use-oriented strategies can "(...) increase the likelihood of successful implementation because they take the end use into account at the beginning design stages" (p. 13).

The practice context of the improvement research is The Netherlands where kindergarten (4-6 years) and elementary school (6-12 years) are integrated. Children normally attend the same school for the first eight years of their education. Three kindergartens agreed to participate in the pilot. The kindergartens were located in, and within a circle of about five miles around, a middle-sized town in the eastern part of the country. One kindergarten teacher from each kindergarten collaborated with the researcher team.

\section{Results}

\subsection{Concept PDKS}

A cluster of activities or tasks which share a psychological, pedagogical, or learning attribute was defined as a skill. A skill (or a set of skills) is related to, or a part of, one or more specific areas of human performance. For example, skills are relevant in development areas or competence domains characterizing youth health, general and developmental psychology, pedagogics, regular education, and inclusive or special and gifted education.

Different types of activities or tasks were specified with respect to development or learning processes within a skill. A regular activity refers to activities or tasks carried out by the learner in order to play, practice, or attain one or more skills. An evaluation activity is an activity or task used to measure the degree of skill of the learner. Psychometric procedures can be used to norm a level of competency with respect to a skill. A normed activity is defined as an evaluation activity or task which is measured on, or can be compared to, a national scale.

The inventory of Dutch instruments and tests for youth aged 0-20 resulted in a concept set of more or less hierarchically structured competence domains and subdomains. These (sub)domains reflect a multi-disciplinary, integrated classification based on measurable skills and (sub)skills made concrete via reliable and valid instruments. The term pedagogical-didactic kernel structure (PDKS) was used to indicate the overall hierarchical structure based on normed instruments to assess related levels of competency, or skills. Additionally, criterion-based evaluative instruments, activities or tasks were introduced in this concept PDKS at places where skills or sub-skills were present or expected, but where no normed indicator was available. These evaluative instruments, activities or tasks were or could be related directly or indirectly to the normed concepts or sub-concepts.

The resulting tentative tree-structures need implementation and validation in educational practice, however. The present concept PDKS contains (sub)skills with respect to the competence domains: 


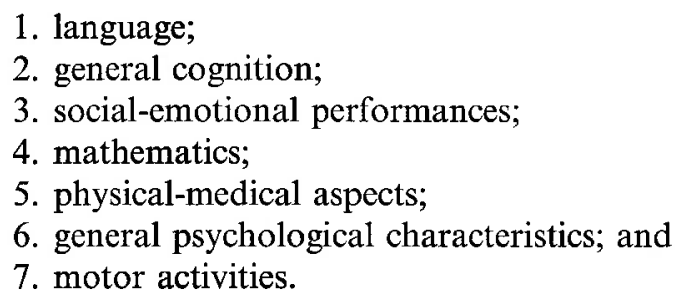

An instructional line was conceptualized as an activity scheme aiming at the realization of a specific level of competence or skill in the context of the PDKS. An instructional line is an activity scheme beginning or ending with an evaluation activity or normed activity. An instructional line can contain one or more evaluative or normed activities or tasks, to evaluate or measure the level of competency or skill of a learner. A learner always plays or works with activities or tasks in a local situation. An instructional line is thus a comprehensive set of activities or tasks which is locally created or selected, usually by a teacher, to enable specific learning processes and outcomes with one or more learners. Evaluation of a learner's competency level or progress with respect to a specific instructional line can be carried out by either one or more of the evaluation activities or tasks, or one or more of the normed activities or tasks.

\subsection{General software prototype}

The software prototype was designed to support the diagnostic creation and use of the concept PDKS at a national scale and the relevant curricular and instructional elements at both a national and a local institutional or school scale. The prototype addresses national research and curriculum development, local curriculum development, and the creation and use of instructional lines by teachers, management, external professionals, and students themselves. From an instructional point of view, the DIMS prototype is intended to assist in creating flexible groupings and to assign a student or group of students to different instructional lines. An overview of the different aspects of the software for users at different levels is presented in Table 4.

The diagnostic, instructional, and management aspects of the software are summarized in the columns on the left side of Table 4. The different levels of users are presented in columns 1-12 on the right side of Table 4 . The combination of the diagnostic, instructional, and management aspects of the software with the different levels of users implies an integrated system. Cells marked with an ' $\mathrm{X}$ ' indicate integration of the aspect in the prototype; cells marked with an ' $O$ ' indicate that development of the aspect has been planned. The multilevel data with regard to the concept PDKS and corresponding instructional lines and learning processes will contribute to the creation of an integrated, longitudinal, and multilevel database. Teachers, parents, school management, other professionals, and research personnel can then obtain a multidimensional perspective on a particular learner's or group of learners' progress on the basis of this information. 
Table 4

Diagnostic, Instructional, Management, and System (DIMS) integration of learning: Design of the general software prototype

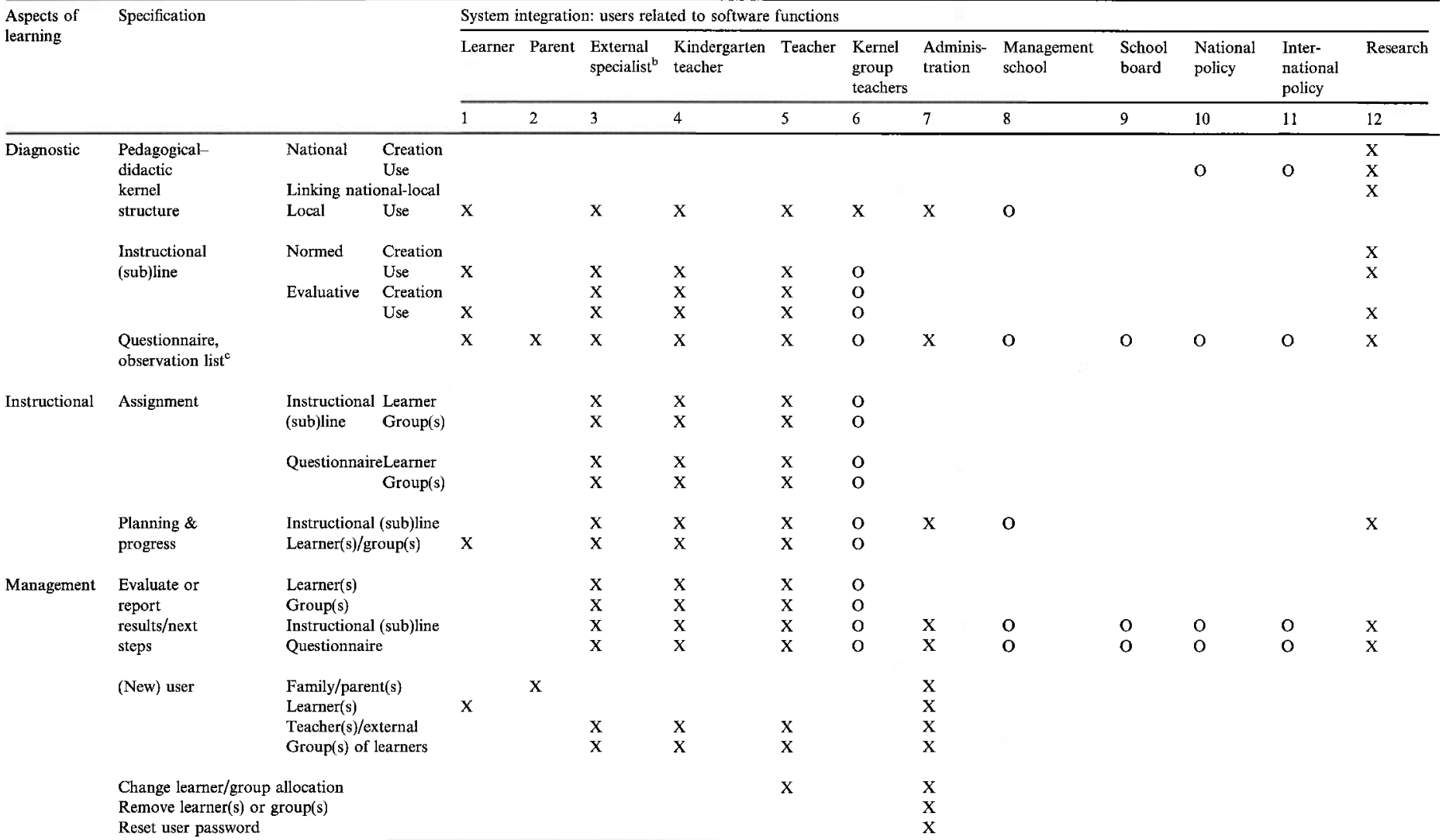

${ }^{a} \mathrm{X}$, realized in November 2004; $\mathrm{O}$, next development.

E.g. external coach, health professional. These persons use the software in collaboration with teachers.

E.g., kindergarten entry characteristics; prosocial behavior; teacher qualities. 
The supposed functioning of the DIMS prototype can be sketched as follows. In Fig. 2, a screen dump of one of the specifications of the concept PDKS is presented. Within the competence domain 'language', sub-domain 'writing', skill 'reading' and subskill 'beginning to read (technical reading)', the focus is on 'sound-letter connection (reading)': see the middle or darkest rectangle in Fig. 2. In this figure (from the left to the right), 'visual analysis' is a precondition to 'visual discrimination'; both 'auditory discrimination' and 'visual discrimination' are preconditions of 'soundletter connection (reading)'; this connection is a precondition to 'visual synthesis', 'sound-letter connection (spelling)' and 'direct word recognition'; and 'sound-letter connection (spelling)' on its turn is a precondition to 'word dictation (a term in testing)'.

Within a local kindergarten or school, each of these concepts can be chosen as an anchoring point for connecting one or more instructional lines characterized by different learning activities and evaluative or normed learning activities. Moreover, different instructional lines can be assigned to one student, a group of students, or groups of students. Students can then receive their learning/playing instructions from the computer in the classroom. The students conduct the playing, learning, or work activities independent of the computer. The students interact with the software to indicate that they have started or completed the specific activity selected for them. The program thus supports the instructional management of student activities, although instructional lines may be designed to include or require computer work. For individual students or groups of students the status of instructional lines is monitored (i.e., planned, currently in use, completed, or ready to be evaluated). The teacher can also add more information in the form of written observations with regard to the student, other teachers, parents, or professionals from outside the school (cf. Chang, 2001).

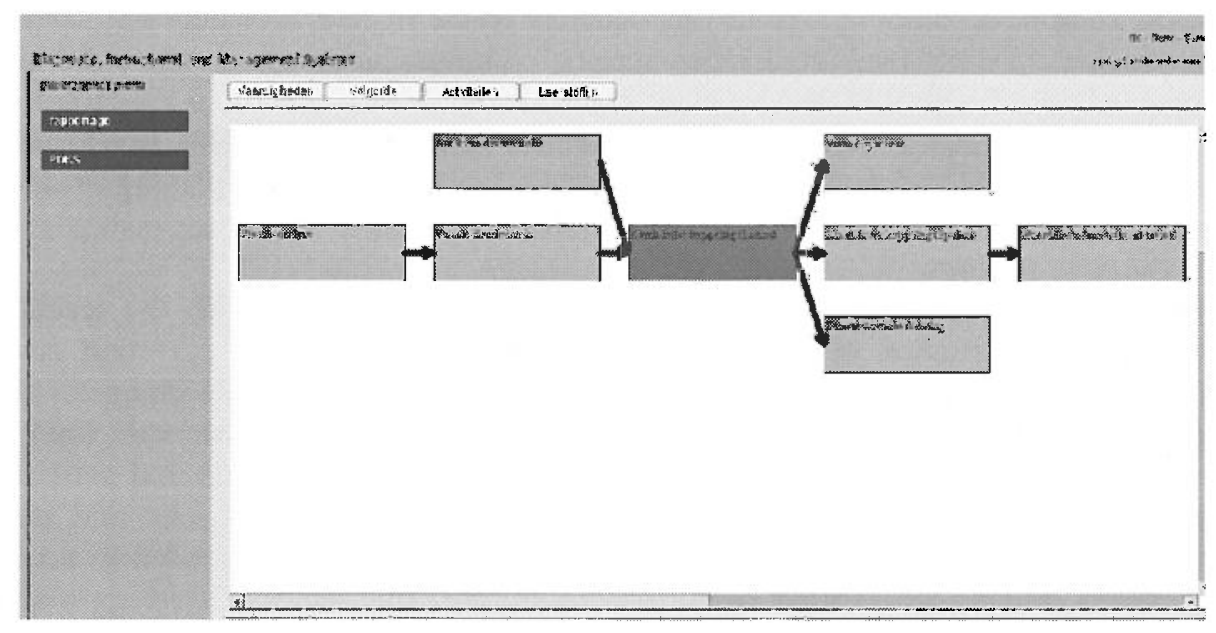

Fig. 2. Screen dump of an example of a skill order (part of the concept PDKS). 


\subsection{Improving kindergarten practice}

Improving development and learning progress starts with the use of a learner's entry characteristics to assign instructional lines (see Table 1, column 4, guideline 1). Therefore, researchers and kindergarten teachers looked for an instrument to estimate the entry characteristics of the kindergarten children. The instrument selected is based upon a psychometrically controlled screening procedure developed with 966 four-year-old children just starting to attend kindergarten (Mooij, 2000). The questionnaire contains seven behavioral rating categories and can be used by the parents at intake and by the kindergarten teacher after the child's first month in kindergarten. The seven categories correspond with the competence domains and refer, respectively, to:

1. social interaction/communication;

2. general cognition;

3. language proficiency;

4. pre-arithmetic;

5. emotional-expressive;

6. sensory-motor; and

7. expected educational behavior.

Scores on a child's entry characteristics can be made by the kindergarten playgroup teacher if the child has gone to such a playgroup, the parents, and the kindergarten teacher. With the aid of software specifications in DIMS the items, item scores, and the means of item categories can be compared numerically and graphically, for parents and teachers. The results of a particular child can also be compared to his or her own group or class, or to normed scores.

The actual use of this screening procedure in practice helped both parents and teachers in getting a clear view of a child's entry characteristics. The intake procedure also assisted in developing a positively oriented frame of reference between parents and teachers: DIMS facilitated more specific communication about the child and supported coordination of development and learning processes both in kindergarten and at home (see also Blumenfeld et al., 2000; Mangione \& Speth, 1998). In addition, the outcome of this screening procedure was used to assign specific playing or diagnostic and learning activities to specific children, as a basis to further pedagogical and didactic support.

At first, this was done without using DIMS. Collaboration with the teachers resulted in construction of some first instructional lines based on play and development or learning aspects. An instructional line was for example characterized by a specific logo (e.g., a simple geometrical shape for a pre-arithmetic line), a specific color and a corresponding name or text. Learning materials and activities within a line were usually ordered by difficulty level, with activities and tests included if desirable or possible. Children were allowed to independently access and return playing or learning resources. To support this self-regulated approach, 
individual children or small groups of children could make use of a planning board (cf. also Mooij, 2002).

Practice experiences showed that working with instructional lines helped to identify possible difficulties in playing, developing and learning. These diagnoses allowed playing and learning to be integrated better, in particular for exceptional children. These experiences convinced the teachers to use DIMS for the construction and use of instructional lines. In cooperation with the teachers, a DIMS interface was designed for students who are not yet able to read. For example, instructional information is mediated by logos, colors, and pictures or photographs of relevant materials. Whether the new learning arrangements do differ from the old ones in their functioning with, or effects on, the young children cannot yet be indicated, however.

\section{Discussion}

The theoretical focus of this paper is on learning as an interactional multilevel process involving diagnostic, instructional, management, and system (DIMS) aspects. In order to enable the integration of major differences in learning across students and particularly those students scoring greatly below or above their peers, three types of contextual conditions were identified as critical: differentiation of learning procedures and materials, design and use of integrating ICT support, and improvement of development and learning progress. When combined with the learning aspects, the contextual conditions create a contextual learning theory which can be summarized in 15 guidelines (see Table 1). The total set of guidelines is expected to provide an individualizing educational system and thereby facilitate the integration of learning differences and multilevel treatment of the learning process. The guidelines also help specify how a nondifferentiating educational system can be transformed into a differentiating, ICT-based instructional management system.

To start the transformation process, a concept pedagogical-didactic kernel structure (PDKS) and a general internet-based software prototype (DIMS) were made concrete. In collaboration with research, three kindergarten teachers started the development of ICT-supported learning arrangements by using a screening instrument with respect to children's entry characteristics. This intake procedure facilitated the communication about children between teacher and parents. Both parties were now using the same language to discuss the child. Highly relevant in the teachers' professional learning from these changes were the observed variations in the children's development levels and learning processes. Also, actual problems or potential risk characteristics of a child could be given more attention in class. The children seemed to receive more systematic - and more immediate - diagnostic or instructional support than they had received prior to the project. Given the present state of practice development, however, it is not yet possible to present systematic quantitative information on the improvement of development and learning processes or outcomes. 
The theoretical design and development characteristics as presented in Tables 1 and 4 suggest a number of future steps for empirical investigation. Next co-development will focus on (a) the user-based development and implementation of the concept PDKS in kindergarten and successive educational types according to the differentiation guidelines in Table 1 , (b) the multilevel integration in practice of instructional lines according to the improvement guidelines, (c) the construction of corresponding user interface specifications in DIMS, and (d) the multilevel measurement and improvement of instructional and learning processes and outcomes (cf. also Blumenfeld et al., 2000; Clark \& Estes, 1999). The results will also provide quantitative evidence regarding the general multilevel hypothesis posited above and suggest further steps for the development of the software prototype and the improvement of educational practice.

The collaboration between research and practice also suggested how to further evolve the present educational system into a more differentiating, ICT-based instructional management system for all learners (a 'multilevel transformation approach': see Mooij, 2004). The main advantage of a PDKS is the continuous curricular support for individual learners or groups of learners in motivating educational contexts. Essential to this transformation process is the realistic, multifold positive evaluation of progress in competency level, e.g., individual and small group progress, progress relative to the small group or class, and progress relative to the age-group. In contrast, the regular Dutch pupil monitoring system only emphasizes a comparison with the age-group, which in the long run usually has negative consequences for the motivation and achievement of students at risk (cf. Collier, 1994; Kemp, 2000). This may also explain why a national campaign to reduce secondary students' bullying and violence seems to have hardly no effects (cf. Mooij, 2005).

Finally, user-based co-development and implementation of both PDKS and DIMS will require a lot of work. And educational transformation is also dependent on the support of local and national educational institutions with innovation, assessment, research, coaching, or policy tasks. Successful optimizing of education asks for a gradually broadening collaboration between institutions involved in educational practices and instruments, at an increasing number of levels, in subsequent educational types (see also Griffin \& Beagles, 2000). However, assistance will be provided by the self-disseminating role of internetbased software and the positive influences of concrete improvements as experienced by teachers, learners, school management, and parents (cf. also Murphy \& Lick, 2001; Remillard, 2000).

\section{Acknowledgments}

Thanks go to Dr. Diana Aarntzen for her work in constructing the concept PDKS and to Ir. Michaël Sperber for the construction of the DIMS prototype. 


\section{References}

Aarnoutse, C., \& Verhoeven, L. (2003). Interventieonderzoek op het gebied van begrijpend lezen: inleiding op het themanummer [Intervention research in the area of comprehensive reading: Introduction to this volume]. Pedagogische Studiën, 80(2), 81-91.

Alschuler, A. S. (1980). School discipline: a socially literate solution. New York: McGraw-Hill.

American Psychiatric Association (1994). Diagnostic and statistical manual of mental disorders (4th ed.). Washington, DC: American Psychiatric Association.

Ames, C. (1984). Competitive, cooperative and individualistic goal structures: a cognitive-motivational analysis. In R. Ames \& C. Ames (Eds.), Student motivation (pp. 177-207). New York: Academic Press.

Ayersman, D. J., \& von Minden, A. (1995). Individual differences, computers, and instruction. Computers in Human Behavior, 11(3-4), 371-390.

Bennathan, M., \& Boxall, M. (1996). Effective intervention in primary schools: Nurture groups. London: David Fulton.

Bennett, W., Jr., Schreiber, B. T., \& Andrews, D. H. (2002). Developing competency-based methods for near-real-time air combat problem solving assessment. Computers in Human Behavior, 18, 773-782.

Bergqvist, K., \& Säljö, R. (1998). Construction of curricular content in the individualised age-integrated classroom. In Paper presented at the European conference on educational research (ECER), September 17-20, Ljubljana, Slovenia.

Bloom, B. (1968). Learning for mastery. Durham, NC: Regional Educational Laboratory for the Carolinas and Virginia.

Blumenfeld, Ph., Fishman, B. J., Krajcik, J., Marx, R. W., \& Soloway, E. (2000). Creating usable innovations in systemic reform: Scaling up technology-embedded project-based science in urban schools. Educational Psychologist, 35, 149-164.

Borko, H., Davinroy, K. H., Bliem, C. L., \& Cumbo, K. B. (2000). Exploring and supporting teacher change: two third-grade teachers' experiences in a mathematics and literacy staff development project. The Elementary School Journal, 100(4), 273-306.

Botting, B., Castilla, E., Mastroiacovo, P., \& Siffel, C. (Eds.) (1998). International clearinghouse for birth defects monitoring systems. Annual Report 1998 with data for 1996. Roma, Italy: The International Centre for Birth Defects.

Brush, Th., \& Saye, J. (2001). Defining hard and soft scaffolding in technology-enhanced student-centered learning environments. In Paper presented at the conference of the Association for Educational Communications and Technology (AECT), November 8-10, Atlanta, USA.

Byme, B. (1998). The foundation of literacy. The childs acquisition of the alphabetic principle. Hove, United Kingdom: Psychology Press.

Calisir, F., \& Gurel, Z. (2003). Influence of text structure and prior knowledge of the learner on reading comprehension, browsing and perceived control. Computers in Human Behavior, 19, 135-145.

Caplan, S. M., Henderson, C. E., Henderson, J., \& Fleming, D. L. (2002). Socioemotional factors contributing to adjustment among early-entrance college students. Gifted Child Quarterly, 46(2), 124-134.

Chalmers, P. A. (2003). The role of cognitive theory in human-computer interface. Computers in Human Behavior, 19(3-4), 593-607.

Chang, C. C. (2001). A study on the cvaluation and effectiveness analysis of web-based learning portfolio. British Journal of Educational Technology, 32, 435-458.

Clark, R. E., \& Estes, F. (1999). The development of authentic educational technologies. Educational Technology, 39(2), 5-16.

Collier, G. (1994). Social origins of mental ability. New York: Wiley.

Cooper, P., \& Ideus, K. (Eds.). (1998). Attention deficit hyperactivity disorder. Educational, medical and cultural issues. Charlton Court, United Kingdom: The Association of Workers for Children with Emotional and Behavioural Difficulties.

Cronbach, L. J. (1970). Essentials of psychological testing. New York: Harper \& Row.

Cronbach, L. J. (1983). Designing evaluations of educational and social programs. San Francisco: JosseyBass. 
Cronbach, L. J., \& Snow, R. E. (1977). Aptitudes and instructional methods. New York: Irvington Publishers.

Crook, Ch. (1998). Children as computer users: The case of collaborative learning. Computers \& Education, 30, 237-247.

Crosier, J. K., Cobb, S., \& Wilson, J. R. (2002). Key lessons for the design and integration of virtual environments in secondary science. Computers \& Education, 38, 77-94.

Davis, G. A., \& Rimm, S. B. (1985). Education of the gifted and talented. Englewood Cliffs, NJ: PrenticeHall.

Davis, J. A. (1966). The campus as a frog pond: an application of the theory of relative deprivation to career decisions of college men. The American Journal of Sociology, 40, 1-10.

Dillenbourg, P. (2002). Over-scripting CSCL: the risks of blending collaborative learning with instructional design. In P. A. Kirschner, W. Jochems, P. Dillenbourg, \& G. Kanselaar (Eds.), Three worlds of CSCL: Can we support CSCL? (pp. 61-91). Heerlen, The Netherlands: Open University.

Durkin, D. (1966). Children who read early. New York: Teachers College Press.

Earle, R. S. (Ed.). (2000). Standards for the accreditation of programs in educational communications and instructional technology (ECIT) (4th ed.). Bloomington, IN: Association for Educational Communications and Technology, rev. October 2001.

Ely, D. P. (1999). Conditions that facilitate the implementation of educational technology innovations. Educational Technology, 39(6), 23-27.

Evers, A., van Vliet-Mulder, J. C., \& Groot, C. J. (2000). Documentatie van tests en testresearch in Nederland [Documentation of tests and test research in The Netherlands]. Assen/Amsterdam, The Netherlands: Van Gorcum/NIP Dienstencentrum.

Evers, A., van Vliet-Mulder, J. C., Resing, W. C. M., Starren, J. C. M. G., van Alphen de Veer, R. J., \& van Boxtel, H. (2002). COTAN. Testboek voor het onderwijs [COTAN. Testbook for education]. Lochem, The Netherlands: NDC Boom.

Freeman, J., \& Josepsson, B. (2002). A gifted programme in Iceland and its effects. High Ability Studies, $13(1), 35-46$.

Frijda, N. H. (1994). Emotionele achtergronden van geweld [Emotional backgrounds to violence]. Justitiële Verkenningen, 20(1), 8-28.

Gallagher, J. J. (1975). Teaching the gifted child. Boston: Allyn and Bacon.

Gardner, J. W. (1961). Excellence. Can we be equal and excellent too? New York: Harper.

Garnier, H. E., Stein, J. A., \& Jacobs, J. E. (1997). The process of dropping out of high school: A 19-year perspective. American Educational Research Journal, 34(2), 395-419.

Gentry, M., Rizza, M. G., \& Owen, S. V. (2002). Examining perceptions of challenge and choice in classrooms: the relationship between teachers and their students and comparisons between gifted students and other students. Gifted Child Quarterly, 46(2), 145-155.

Gilsing, R., Roes, Th., Veldheer, V., \& Vorthoren, M. (2000). Knelpunten in het stedelijk jeugdbeleid [Frictions in communal youth policy]. The Hague, The Netherlands: Sociaal en Cultureel Planbureau.

Goleman, D. (1995). Emotional intelligence. New York: Bantam Books.

Griffin, S. L., \& Beagles, Ch. A. (2000). Training and performance support systems (TPSS): A case study from needs assessment to return on investment. Educational Technology, 40(5), 34-42.

Gross, M. U. M. (1992). The use of radical acceleration in cases of extreme intellectual precocity. Gifted Child Quarterly, 36(2), 91-99.

Gross, M. U. M. (1996). Giftedness, motivation and self-esteem: effects of full-time grouping. In Thematic paper session at the ECHA conference 'Creativity \& Culture', Vienna, October 19-22.

Gross, M. U. M. (2001). Musings: Serving gifted students in schools - Bland protestations or practical action? Understanding Our Gifted, 13(2), 16-18.

Gustafson, K. (2002). Instructional design tools: a critique and projections for the future. Educational Technology Research and Development, 50(4), 59-66.

Heckhausen, H. (1980). Motivation und Handeln: Lehrbuch der Motivationspsychologie [Motivation and action: Handbook of motivational psychology]. Berlin: Springer.

Hille, E. T. M., den Ouden, A. L., Bauer, L., van den Oudenrijn, C., Brand, R., \& VerlooveVanhorick, S. P. (1994). School performance at nine years of age in very premature and very low 
birth weight infants: Perinatal risk factors and predictors at five years of age. The Journal of Pediatrics, $125(3), 426-434$.

Hooper, S. (2003). The effects of persistence and small group interaction during computer-based instruction. Computers in Human Behavior, 19, 211-220.

Jellen, H. G., \& Urban, K. K. (1986). The TCT-DP (test for creative thinking - drawing production); an instrument that can be applied to most age and ability groups. The creative child and adult quarterly, 11 , $138-155$.

Jewett, J., Tertell, L., King-Taylor, M., Parker, D., Tertell, L., \& Orr, M. (1998). Four early childhood teachers reflect on helping children with special needs make the transition to kindergarten. The Elementary School Journal, 98, 329-338.

Jochems, W. (2002). CSCL, three worlds compared: Computer supported collaborative learning in distance and face-to-face education. In P. A. Kirschner, W. Jochems, P. Dillenbourg, \& G. Kanselaar (Eds.), Three worlds of CSCL: Can we support CSCL? (pp 49-59). Heerlen, The Netherlands: Open University.

Johnsen, S. K., Haensly, P. A., Ryser, G. R., \& Ford, R. F. (2002). Changing general education classroom practices to adapt for gifted students. Gifted Child Quarterly, 46(1), 45-63.

Jones, B. F., Rasmussen, C. M., \& Moffitt, M. C. (1997). Real-life problem solving. A collaborative approach to interdisciplinary learning. Washington, DC: American Psychological Association.

Jones, I., Gullo, D. F., Burton-Maxwell, C., \& Stoiber, K. (1998). Social and academic effects of varying types of early schooling experiences. Early Child Development and Care, 146, 1-11.

Kalyuga, S., Ayres, P., Chandler, P., \& Sweller, J. (2003). The expertise reversal shift. Educational Psychologist, 38, 23-31.

Kanselaar, G. (2002). Co-construction of knowledge in computer supported collaborative argumentation. In P. A. Kirschner, W. Jochems, P. Dillenbourg, \& G. Kanselaar (Eds.), Three worlds of CSCL: Can we support CSCL? (pp 93-130). Heerlen, The Netherlands: Open University.

Kaplan, A., Gheen, M., \& Midgley, C. (2002). Classroom goal structure and student disruptive behaviour. British Journal of Educational Psychology, 72, 191-211.

Kemp, J. E. (2000). An interactive guidebook for designing education in the 21st century. Bloomington, Indiana: Technos Press of the Agency for Instructional Technology (AIT)/Association for Educational Communications and Technology (AECT).

Kensing, F., Simonsen, J., \& Bødker, K. (1998). MUST: A method for participatory design. HumanComputer Interaction, 13, 167-198.

Khatena, J. (1982). Educational psychology of the gifted. New York: Wiley.

King, E., O'Shea, A. A., Joy Patyk, L. I., Popp, L. A., Runions, T., Shearer, J., et al. (1985). Programming for the gifted. Ontario, Canada: Ministry of Education.

Kirschner, P. A. (2002). Can we support CSCL? Educational, social and technological affordances for learning. In P. A. Kirschner, W. Jochems, P. Dillenbourg, \& G. Kanselaar (Eds.), Three worlds of CSCL: Can we support CSCL? (pp 7-47). Heerlen, The Netherlands: Open University.

Kounin, J. S. (1970). Discipline and group management in classrooms. New York: Holt, Rinehart and Winston.

Kreijns, K., Kirschner, P. A., \& Jochems, W. (2003). Identifying the pitfalls for social interaction in computer-supported collaborative learning environments: a review of the research. Computers in Human Behavior, 19, 335-353.

Kuhlemeier, H., Kleintjes, F., \& van den Bergh, H. (2001). Effect van toetsvorm en vraagtype op de moeilijkheid van de afsluitingstoetsen basisvorming: Een toepassing van multiniveau analyse met random kruisclassificatie [Effect of type of test and type of questioning on the degree of difficulty of the final tests in basic education: An application of multilevel analysis with random cross-classification]. Pedagogische Studiën, 78(3), 197-211.

Kuo, C.-H., Wible, D., Chen, M.-C., Sung, L.-C., Tsao, N.-L., \& Chio, C.-L. (2002). The design of an intelligent web-based interactive language learning system. Journal of Educational Computing Research, 27(3), 229-248.

Lajoie, S. P. (2003). Individual differences in spatial ability: developing technologies to increase strategy awareness and skills. Educational Psychologist, 38, 115-125. 
Leseman, P. P. M. (2002). Onderzoek in de voor- en vroegschoolse periode: trends en nieuwe vragen [Preschool and early schooling research: trends and new questions]. The Hague, The Netherlands: NWO/ PROO.

Lloyd, L. (1999). Multi-age classes and high ability students. Review of Educational Research, 69(2), 187-212.

Lohman, D. F. (1990). When good programs have bad effects on good students: understanding mathematical effects in thinking skills programs. In M. J. Ippel \& J. J. Elshout (Eds.), Training van hogere-orde vaardigheden [Training higher-order skills] (pp. 21-30). Lisse, The Netherlands: Swets \& Zeitlinger.

Magnusson, D., \& Allen, V. L. (Eds.). (1983). Human development. An interactional perspective. New York: Academic Press.

Mangione, P. K., \& Speth, T. (1998). The transition to elementary school: A framework for creating early childhood continuity through home, school, and community partnerships. The Elementary School Journal, 98, 381-397.

Marjoribanks, K. (1994). Families, schools and children's learning: a study of children's learning environments. International Journal of Educational Research, 21, 441-555.

Massé, L., \& Gagné, F. (2002). Gifts and talents as sources of envy in high school settings. Gifted Child Quarterly, 46(1), 15-29.

Mehlhorn, H.-G. (1988). Persönlichkeitsentwicklung Hochbegabter [Personality development of gifted persons]. Berlin: Volk und Wissen Volkseigener Verlag.

Meijer, C. J. W. (Ed.) (2001). Inclusive education and effective classroom practices. European Agency for Development in Special Needs Education. Available from http://www.european-agency.org.

Meijer, C. J. W. (Ed.) (2003). Inclusive education and classroom practices. Summary report. European Agency for Development in Special Needs Education. Available from http://www.european-agency. org.

Meisels, S. J., DiPrima Bickel, D., Nicholson, J., Xue, Y., \& Atkins-Burnett, S. (2001). Trusting teachers' judgments: a validity study of a curriculum-embedded performance assessment in kindergarten to grade 3. American Educational Research Journal, 38(1), 73-95.

Mönks, F. J., \& Lehwald, G. (Eds.). (1991). Neugier, Erkundung und Begabung bei Kleinkindern [Curiosity, searching for information, and giftedness with young children]. München, Germany: Ernst Reinhardt Verlag.

Mooij, T. (1999). Integrating gifted children into kindergarten by improving educational processes. Gifted Child Quarterly, 43(2), 63-74.

Mooij, T. (2000). Screening children's entry characteristics in kindergarten. Early Child Development and Care, $165,23-40$.

Mooij, T. (2002). Designing a digital instructional management system to optimize early education. Educational Technology Research \& Development, 50(4), 11-23.

Mooij, T. (2004), Optimising ICT effectiveness in instruction and learning: multilevel transformation theory and a pilot project in secondary education. Computers \& Education, 42(1), 25-44.

Mooij, T. (2005). National campaign effects on secondary pupils' bullying and violence. British Journal of Educational Psychology, 75(3), 489-511.

Mooij, T. (in press). Contextual learning theory: concrete form and a software prototype to improve early education. Computers \& Education.

Mooij, T., Terwel, J., \& Huber, G. (2000). A social perspective on new learning. In R.-J. Simons, J. van der Linden, \& T. Duffy (Eds.), New learning (pp. 191-208). Dordrecht, The Netherlands: Kluwer.

Murphy, C. U., \& Lick, D. W. (2001). Whole-faculty study groups. Creating student-based professional development (2nd ed.). Thousand Oaks, CA: Corwin Press.

Nadolski, R. J., Kirschner, P. A., van Merriënboer, J. J. G., \& Hummel, H. G. K. (2001). A model for optimizing step size of learning tasks in competency-based multimedia practicals. Educational Technology Research \& Development, 49, 87-103.

Neber, H., \& Schommer-Aikins, M. (2002). Self-regulated science learning with highly gifted students: the role of cognitive, motivational, epistemological, and environmental variables. High Ability Studies, 13(1), 59-74. 
O'Neil, H. F., Jr., Ni, Y., Baker, E. L., \& Wittrock, M. C. (2002). Assessing problem solving in expert systems using human benchmarking. Computers in Human Behavior, 18, 745-759.

Paas, F., Renkl, A., \& Sweller, J. (2003). Cognitive load theory and instructional design: recent developments. Educational Psychologist, 38, 1-4.

Parkhurst, H. (1922). Education on the Dalton Plan. New York: Dutton.

Peetsma, T., van der Veen, I., Koopman, P., \& van Schooten, E. (2003). Kan een eenzijdige klassamenstelling de ontwikkeling van leerlingen afremmen? Effecten van de sociale en etnische klassamenstelling en verschillen hierin tussen groepen [Effects of the social and ethnic class composition in elementary school, and differences concerning this for children with various social and ethnic backgrounds]. Pedagogische Studiën, 80, 339-357.

Pellegrini, A. D., \& Boyd, B. (1993). The role of play in early childhood development and education: Issues in definition and function. In B. Spodek (Ed.), Handbook of research on the education of young children (pp. 105-121). New York: MacMillan.

Proudfoot, J., Swain, S., Widmer, S., Watkins, E., Goldberg, D., Marks, I., et al. (2003). The development and beta-test of a computer-therapy program for anxiety and depression: hurdles and lessons. Computers in Human Behavior, 19, 277-289.

Purcell, J. H., Burns, D. E., Tomlinson, C. A., Imbeau, M. B., \& Martin, J. L. (2002). Bridging the gap: a tool and technique to analyze and evaluate gifted education curricular units. Gifted Child Quarterly, 46(4), 306-321.

Raver, C. C., \& Zigler, E. F. (1997). Social competence: an untapped dimension in evaluating Head Start's success. Early Childhood Research Quarterly, 12(4), 363-385.

Remillard, J. T. (2000). Can curriculum materials support teachers' learning? Two fourth-grade teachers' use of a new mathematics text. The Elementary School Journal, 100, 331-350.

Resing, W. C. M., Evers, A., Koomen, H. M. Y., Pameijer, N. K., Bleichrodt, N., van Boxtel, H., et al. (2002). Indicatiestelling: Condities en instrumentarium in het kader van leerlinggebonden financiering [Special education indication: Conditions and instruments within the framework of financing individual students]. Lochem, The Netherlands: NDC Boom.

Schnotz, W., \& Lowe, R. (2003). External and internal representations in multimedia learning. Learning and Instruction, 13(2), 117-123.

Sherman, L. W., Gottfredson, D. C., MacKenzie, D. L., Eck, J., Reuter, P., \& Bushway, S. D. (1998). Preventing crime: what works, what doesn't, what's promising. U.S. Department of Justice, Office of Justice Programs, National Institute of Justice. Available from www.ojp.usdoj.gov/nij/ rsrcdocs.htm\#1998.

Sinko, M., \& Lehtinen, E. (1999). The challenges of ICT in finnish education. Finland, Atena: Jyväskylä.

Skinner, D., Bryant, D., Coffman, J., \& Campbell, F. (1998). Creating risk and promise children's and teachers' coconstructions in the cultural world of kindergarten. The Elementary School Journal, 98(4), 297-310.

Sternberg, R. J., \& Grigorenko, E. L. (2002). The theory of successful intelligence as a basis for gifted education. Gifted Child Quarterly, 46(4), 265-277.

Tennyson, R. D., \& Breuer, K. (2002). Improving problem solving and creativity through use of complexdynamic simulations. Computers in Human Behavior, 18, 650-668.

Underwood, J. D. M. (2003). Student attitudes towards socially acceptable and unacceptable group working practices. British Journal of Psychology, 94, 319-337.

U.S. Department of Health, Education and Welfare (1973). Positive approaches to dropout prevention. Washington, DC: U.S. Government Printing Office.

van den Akker, J. (1999). Principles and methods of development research. In J. van den Akker, R. Maribe Branch, K. Gustafson, N. Nieveen, \& Tj. Plomp (Eds.), Design approaches and tools in education and training (pp. 1-14). Dordrecht, The Netherlands: Kluwer.

van den Einden, H., \& Pecht, R. (1995). De groene spelen [The green plays]. Nikko Toshogu Press.

van Merriënboer, J. J. G. (1997). Training complex cognitive skills. Englewood Cliffs, NJ: Educational Technology Publications.

van Merriënboer, J. J. G., Kirschner, P. A., \& Kester, L. (2003). Taking the load off a learner's mind: instructional design for complex learning. Educational Psychologist, 38(1), 5-13. 
Veenman, M. J. V., Prins, F. J., \& Elshout, J. J. (2002). Initial inductive learning in a complex computer simulated environment: the role of metacognitive skills and intellectual ability. Computers in Human Behavior, 18, 327-341.

Walker, H. M., Kavanagh, K., Stiller, B., Golly, A., Severson, H. H., \& Feil, E. G. (1998). First step to success: An early intervention approach for preventing school antisocial behavior. Journal of Emotional and Behavioral Disorders, 6(2), 66-80.

Watkins, A. (2001). Information and communication technology (ICT) in special needs education (SNE). European Agency for Development in Special Needs Education. Available from http://www.europeanagency.org.

Wilson, B. G. (1999). Evolution of learning technologies: From instructional design to performance support to network systems. Educational Technology, 39(2), 32-35. 